\title{
EERC-DOE ENVIRONMENTAL TECHNOLOGY ACCEPTANCE
}

Semiannual Report

for the period October 1, 2001 - March 31, 2002

(including the Quarterly Status Report for the period January 1-March 31, 2002)

Prepared for:

AAD Document Control

U.S. Department of Energy

National Energy Technology Laboratory

PO Box 10940, MS 921-I07

Pittsburgh, PA 15236-0940

Cooperative Agreement No. DE-FC26-00NT40840

Performance Monitor: Edgar Klunder

Prepared by:

Christina B. Behr-Andres, Ph.D., P.E.

Energy \& Environmental Research Center

University of North Dakota

PO Box 9018

Grand Forks, ND 58202-9018 


\section{DISCLAIMER}

This report was prepared as an account of work sponsored by an agency of the United States Government. Neither the United States Government, nor any agency thereof, nor any of their employees make any warranty, express or implied, or assumes any legal liability or responsibility for the accuracy, completeness, or usefulness of any information, apparatus, product, or process disclosed or represents that its use would not infringe privately owned rights. Reference herein to any specific commercial product, process, or service by trade name, trademark, manufacturer, or otherwise does not necessarily constitute or imply its endorsement, recommendation, or favoring by the United States Government or any agency thereof. The views and opinions of authors expressed herein do not necessarily state or reflect those of the United States Government or any agency thereof.

\section{EERC DISCLAIMER}

LEGAL NOTICE This research report was prepared by the Energy \& Environmental Research Center (EERC), an agency of the University of North Dakota, as an account of work sponsored by the U.S. Department of Energy (DOE). Because of the research nature of the work performed, neither the EERC nor any of its employees make any warranty, express or implied, or assume any legal liability or responsibility for the accuracy, completeness, or usefulness of any information, apparatus, product, or process disclosed, or represent that its use would not infringe privately owned rights. Reference herein to any specific commercial product, process, or service by trade name, trademark, manufacturer, or otherwise does not necessarily constitute or imply its endorsement or recommendation by the EERC.

This report is available to the public from the National Technical Information Service, U.S. Department of Commerce, 5285 Port Royal Road, Springfield, VA 22161; phone orders accepted at (703) $487-4650$.

\section{ACKNOWLEDGMENT}

This report was prepared with the support of the DOE National Energy Technology Laboratory Cooperative Agreement No. DE-FC26-00NT40840. However, any opinions, findings, conclusions, or recommendations expressed herein are those of the authors(s) and do not necessarily reflect the views of DOE. 


\section{TABLE OF CONTENTS}

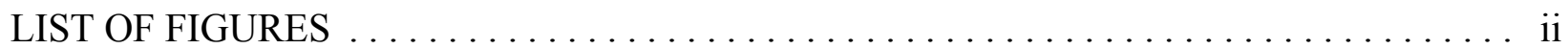

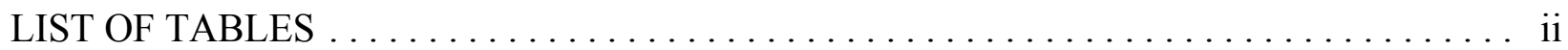

TASK 2A - LONG-TERM STEWARDSHIP . . . . . . . . . . . . . . . . . . . 1

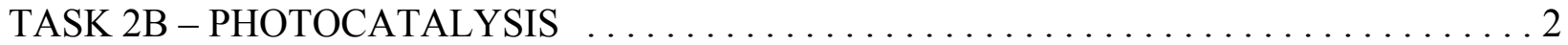

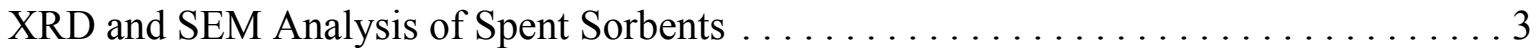

TASK 2C - SUBCRITICAL WATER TREATMENT OF CONTAMINATED PAINT

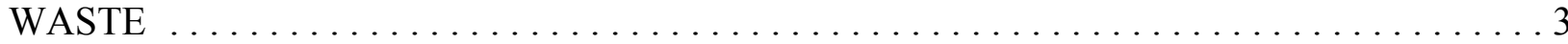

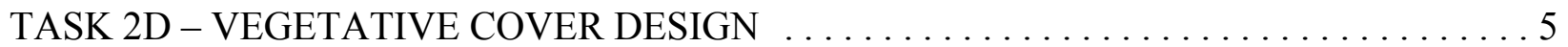

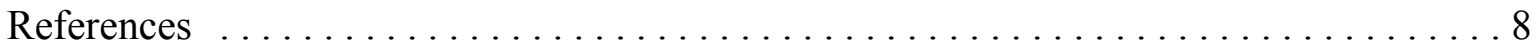

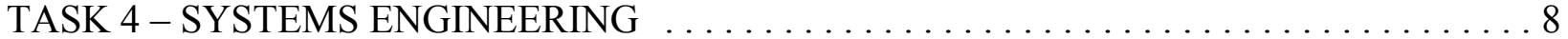

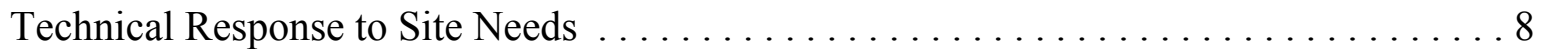

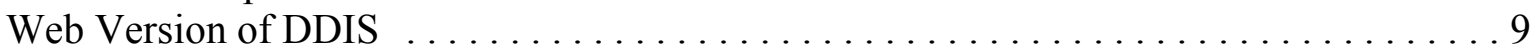

Site End Users . . . . . . . . . . . . . . . . . . . . . . . . . 9

Technology Vendors/Developers ............................. 9

Complexwide Technology Assistance - EMTAS . . . . . . . . . . . . . . . . . . . 9 


\section{LIST OF FIGURES}

1 ECap ${ }^{\mathrm{TM}}$ "sponge-and-pump" mechanism $\ldots \ldots \ldots \ldots \ldots \ldots \ldots \ldots \ldots \ldots \ldots \ldots \ldots \ldots$

\section{LIST OF TABLES}

1 Concentrations of Metals Present in Paint Determined by ICP-MS . . . . . . . . . . . 4

2 Effectiveness of Different Metals on PCB Dechlorination in Subcritical Water ....... 5 


\section{EERC-DOE ENVIRONMENTAL TECHNOLOGY ACCEPTANCE}

\section{TASK 2A - LONG-TERM STEWARDSHIP}

As a member of the Mound Long-Term Stewardship Initiative (LTSI) Technology Team (TT), the Energy \& Environmental Research Center (EERC) was tasked with creating a database that was capable of storing critical information related to complexwide long-term stewardship (LTS) needs. The Long-Term Stewardship Information System (LTSIS) was developed to employ unique search techniques to examine relationships in an inventory of vendor technologies and complexwide LTS needs. This system will provide a context for the Mound needs assessment and provide summary information about LTS needs throughout the complex.

Development of the LTSIS database occurred in two phases:

1) A complexwide LTS needs assessment was conducted by reviewing LTS needs from various sites across the complex for inclusion in the database. All LTS needs from the Integrated Planning, Accountability, and Budgeting System (IPABS) database as well as needs taken directly from site-technology coordination group (STCG) Web sites and site interviews were included. Needs were then coded, based upon the properties that define them, and inserted into the database.

2) A site-specific technology assessment for the Mound site was performed using various methods, including Internet (existing database) searches, workshop/conference vendor queries, and collaboration with TT members. Similar to the needs assessment, information obtained through technology evaluations was characterized according to need properties and matched. The EERC, supported by DIAL and TechCon, used information gathered during this phase of the project to create a list of invitees to the Mound Vendor Workshop held in April.

The EERC assists Mound with its LTS planning through participation in bimonthly TT conference calls, meetings, workshops, and conferences. The following is a listing of functions attended by the EERC:

- ITRC Fall Conference, Long Beach, California

- TIE Conference, Albuquerque, New Mexico

- Environmental Stewardship: Promises and Uncertainties Symposium, New Orleans, Louisiana

- Waste Management Conference, Tucson, Arizona

- Mound Vendor Workshop, Dayton, Ohio 
Barry Botnen will present a paper outlining the LTSIS database at the SPECTRUM 2002 Conference in Reno, Nevada, in August 2002.

LTS needs, along with technologies to address the needs, will continue to be reviewed for inclusion in the LTSIS. This process will identify "technology gaps" (needs without solutions) and direct future research and development activities.

\section{TASK 2B - PHOTOCATALYSIS}

The photocatalytic reactor system was received and installed. The primary system component consists of a 48-inch-tall, 6-inch-diameter borosilicate glass column with a centrally located, 40-watt black lightbulb encased in a 2 -inch-diameter borosilicate glass column. The reactor system was first subjected to hydrodynamic testing to ensure proper operation without leaks.

Chemicals for the surrogate test solution were ordered and received. The test solution used for preliminary trials to develop breakthrough curves is relatively simple, consisting of mercuric chloride as a mercury source and glucose as an organic reducing agent.

Samples of agglomerated $\mathrm{TiO}_{2}$ sorbents impregnated with the noble metal were received from ADA Technologies. Several size fractions of the sorbent were provided.

Test trials were performed to determine the activity of the $\mathrm{TiO}_{2}$ sorbent for mercury sorption and reduction. Mercury concentration in the solution and amount of photocatalyst were changed in order to determine the optimal amount of sorbent and to observe the effect of initial mercury concentration on process performance. Test reactions were performed in a batch mode in a glass beaker. The solution was illuminated with 40 -watt black lightbulb from the top. The reaction mixture was magnetically stirred before (allowing the reagents to adsorb onto catalyst surface) and during exposure to ultraviolet (UV) light.

During the test, samples of the reaction mixture were taken. After sorbent separation $(0.45-\mu \mathrm{m}$ membrane filter), the solution was analyzed for mercury content using an atomic absorption method.

Initial mercury concentrations in a series of tests were as follows: $1,10,40$, and $50 \mathrm{mg} / \mathrm{L}$. Glucose concentrations in the surrogate solution were always five times that of the initial mercury concentration to ensure sufficient amounts of reducing agent were available in the reaction system.

The observations and results of conducted experiments are summarized as follows:

- The optimal amount of sorbent was found to be $1 \mathrm{~g} / \mathrm{L}$.

- The higher the initial mercury concentration in the solution, the higher the photocatalytic reaction rate.

- Photocatalyst particles attrit during the process. 
- Upon reaction, the photocatalyst changes color from light purple to gray.

One test experiment was performed to determine the sorption capacity of the catalyst for mercury adsorption. The initial mercury concentration in the solution was $50 \mathrm{mg} / \mathrm{L}$, and the sorbent amount was $1 \mathrm{~g} / \mathrm{L}$. The reaction solution was magnetically stirred for 1 hour and then illuminated with two 40-watt UV black lightbulbs.

After 5 hours of illumination, the samples for mercury and glucose analysis were taken and the solution was left overnight. The next day, the photocatalyst was separated and reused, with the new solution having the same concentrations of mercury and glucose as the day before. This procedure was repeated for five days.

A change in sorbent coloration was observed during this experiment: fresh material is light purple, while after two days, the color became gray. It was also observed that the sorbent particles were breaking up. When the experiment was finished, the spent sorbent was a very fine powder. Addition of a second UV bulb improved catalyst performance, but it lost the activity after the four days of experiment. The glucose analysis showed that about $50 \mathrm{mg} / \mathrm{L}$ of glucose was oxidized during mercury reduction during each experiment.

\section{XRD and SEM Analysis of Spent Sorbents}

Two samples of spent catalyst were analyzed. The first one was taken after a short time of photocatalytic reaction (Sample 1). The second one was taken after the last test, which went on for five days (Sample 2). X-ray diffraction (XRD) analysis showed that the major phases in Sample 1 were anatase, calomel $(\mathrm{HgCl})$, and rutile $\left(\mathrm{TiO}_{2}\right)$. Minor phases were gold and, possibly, mercury chloride $\left(\mathrm{HgCl}_{2}\right)$.

Scanning electron microscopy (SEM) analysis of this sample did not show the presence of metallic mercury, and there was no trace of mercury-gold amalgamation. The only mercury form present in this sample was calomel. This shows that the reduction of $\mathrm{Hg}^{2+}$ ion did not proceed to the end (metallic form) - it stopped at $\mathrm{Hg}^{+}$.

XRD analysis of Sample 2 showed that the major phases were anatase and calomel. The minor phase was rutile. SEM analysis of this sample showed the presence of both calomel and metallic mercury. Images show that big agglomerates are present on the surface of the catalyst, much bigger than those in Sample 1. Likewise, as in the case of Sample 1, there is no trace of mercury-gold amalgamation.

\section{TASK 2C -SUBCRITICAL WATER TREATMENT OF CONTAMINATED PAINT WASTE}

ICP-MS (inductively coupled plasma-mass spectrometry) analysis of the paint chips was performed to determine if metals content of the paint could explain the faster dechlorination of polychlorinated biphenyls (PCBs) in paint which occurs compared to standard PCBs. High concentrations of lead, nickel, and iron were found, as well as a variety of other metals, as shown in Table 1. 
Tests with potentially active metals for the dechlorination of PCB standards were also performed. All tests were carried out at $300^{\circ} \mathrm{C}$ for 60 minutes using $100 \mathrm{mg}$ of the test metal, $1 \mathrm{mg}$ of PCBs (Aroclor 1254), and $2 \mathrm{~mL}$ of water. These tests indicate that lead and nickel enhance PCB dechlorination more than iron. Only nickel was available in two particle-size ranges, 3 and 45 microns. Comparison of these two particle sizes shows that finer metal particles are more effective. When lead and nickel are compared using the same particle size (45 microns), lead is the most effective, as shown in Table 2.

A work plan to perform additional investigation into the effect of metal reactants on the PCB dechlorination was received from Professor Chien Wai at the University of Idaho. A request to amend the EERC's contract to include a subcontract to Professor Wai is being prepared for submission to the U.S. Department of Energy (DOE).

Table 1. Concentrations of Metals Present in Paint Determined by ICP-MS

\begin{tabular}{lc}
\hline Metal & Concentration, $\mathrm{mg} / \mathrm{g}$ \\
\hline Iron & 14 \\
Zinc & 22 \\
Lead & 7 \\
Chromium & 4 \\
Copper & 0.2 \\
Cobalt & 0.27 \\
Manganese & 0.2 \\
Nickel & 0.06 \\
Titanium & 0.06 \\
Barium & 0.04 \\
Cadmium & 0.02 \\
\hline
\end{tabular}




\begin{tabular}{|c|c|c|}
\hline Metal & Particle Size, microns & \% PCBs Degraded \\
\hline Iron & $1-5$ & $68 \pm 6$ \\
\hline Copper & $1-5$ & $52 \pm 6$ \\
\hline Nickel & 3 & $84 \pm 1$ \\
\hline Nickel & 45 & $57 \pm 6$ \\
\hline Lead & 45 & $78 \pm 3$ \\
\hline
\end{tabular}

\section{TASK 2D - VEGETATIVE COVER DESIGN}

DOE has begun to evaluate the application of vegetative covers to low-level waste (LLW) repositories and other radionuclide-contaminated areas. According to a presentation by Dr. Michael Serrato at the WM02 Waste Management Symposium held in February 2002 in Tucson, Arizona, many acres at the weapons sites have capping needs that are currently not being met, including more than 250 acres at the Savannah River Site (SRS), more than 750 acres at Idaho National Engineering and Environmental Laboratory (INEEL), over 750 acres at Los Alamos National Laboratory, and in excess of 500 acres at Hanford. This acreage does not include the future needs for evapotranspiration (ET) vegetative covers that may exist at closure sites (1).

The EERC is collaborating with Ecolotree ${ }^{\circledR}$, Inc., of North Liberty, Iowa, to design a prototype of an appropriate vegetative cover system using indigenous plants and incorporating the idea of succession of plant species over time. Ecolotree ${ }^{\mathbb{B}}$ holds a patent for the use of tree crops as pollutant controls (U.S. Patent No. 5,947,041) and designs and installs two types of systems: Ecolotree ${ }^{\circledR}$ Cap $\left(\mathrm{ECap}^{\mathrm{TM}}\right)$ and Ecolotree ${ }^{\circledR}$ Buffer (EBuffer). The ECap ${ }^{\mathrm{TM}}$ minimizes unwanted water percolation into waste by a "sponge-and-pump" mechanism that is illustrated in Figure 1. The ECap ${ }^{\mathrm{TM}}$ consists of specially prepared soils planted with fast-growing trees and understory grasses. The soil pores hold precipitation like a sponge until plant roots can access the water. Plants take up this water for growth and release it into the atmosphere by transpiration. ECaps $^{\mathrm{TM}}$ are designed to minimize the volume of water that penetrates into landfill waste or contaminated soils, thus reducing contaminant movement into groundwater and surface waters. $\mathrm{ECaps}^{\mathrm{TM}}$ are also used to minimize surface soil erosion.

Ecolotree ${ }^{\circledR}$ has been asked to participate in the U.S. Environmental Protection Agency's (EPA's) Alternative Cover Assessment Program (ACAP) more than once. Information about ACAP can be found on the Web at http://www.dri.edu/Projects/EPA/boston-brochure2.html. At the ACAP site at Albany, Georgia, the $\mathrm{ECap}^{\mathrm{TM}}$ is significantly outperforming both a clay cap and a geomembrane cap. Since approximately Day 175 of the test, the ECap ${ }^{\mathrm{TM}}$ has not permitted any water percolation into the waste. 


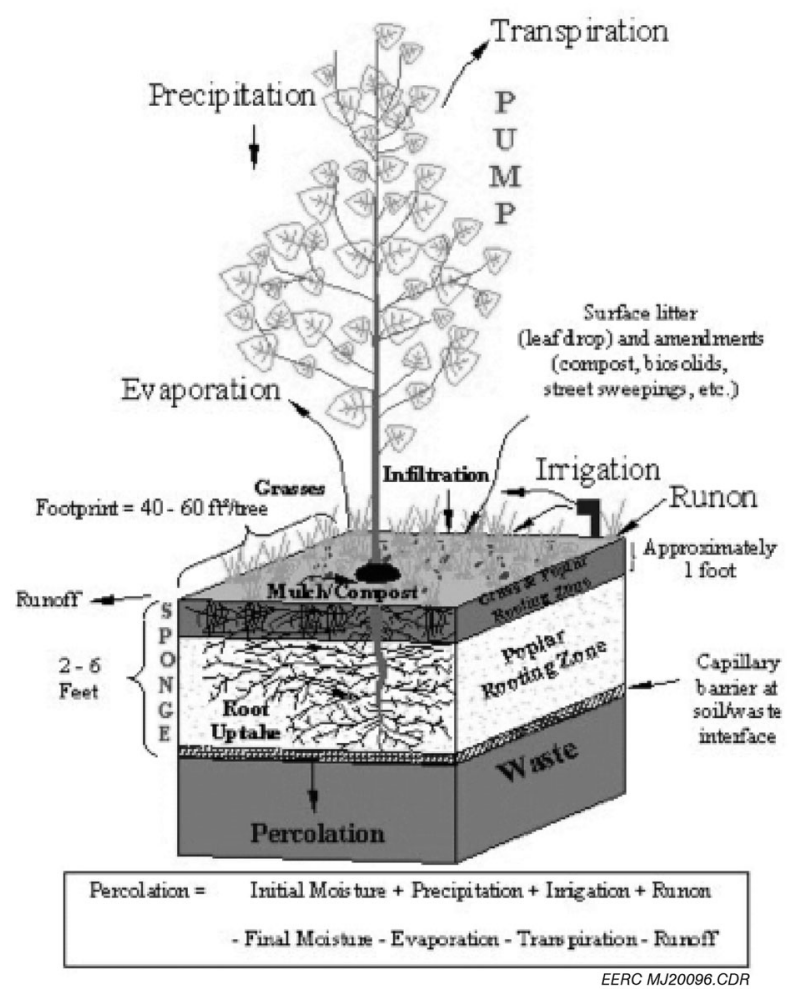

Figure 1. ECap ${ }^{\mathrm{TM}}$ "sponge-and-pump" mechanism (figure from Ecolotree ${ }^{\circledR}$, Inc., Web site).

The goal of this ETA project is to further develop the concept of using ET vegetative covers for LLW repositories. While application of the concept is under way at a few locations, the idea of planting specific high-performance tree species (such as poplars) and indigenous vascular plants with an eye toward planned plant succession has not been implemented. Therefore, the objectives of this project that will ensure that the project goal is met include 1) defining specific vegetative cover needs for LLW repositories in humid environments (arid environment requirements have been identified during other research), 2) collecting data required for design and modeling of an ET vegetative cover, 3) actual design and modeling of this type of cover, and 4) evaluating the costs and transferability of the design to other LLW repositories in the DOE complex. The original project plan called for design of an ET vegetative cover for a LLW repository at SRS.

Hydrus-2D software will be used during this project to model the water balance for the ET cover; i.e., the water movement into, within, and out of the cover. Data that are required for input into this modeling software include water flow information; root water uptake; geometry of the cover; soil type; number of layers; boundary conditions; and climatic data including worst- and bestcase conditions, average precipitation, humidity, etc. A copy of Version 2.02 of Hydrus 2-D was procured from the International Ground Water Modeling Center. The computer capabilities of project personnel were upgraded to facilitate the use of this rather memory-intensive software.

Project personnel used literature and Internet searches to identify the vegetative cover needs of the DOE complex that are under the purview of the Nevada, Albuquerque, Rocky Flats, Ohio, and 
Savannah River operations offices. Publicly available information about the nature of the waste found at the sites targeted for vegetative caps was reviewed.

Because the original project work plan called for the design of an ET cover suitable for installation at a LLW repository at SRS, plant species native to South Carolina were identified. The NatureServe Explorer database (3) was used to identify 3193 vascular plants, including conifers, ferns, flowering plants, deciduous trees, and grasses that could be used as part of a successional plan.

Several trips were taken to expand the project team's knowledge base with respect to ET vegetative covers. Melanie Jensen and Bethany Bolles visited Ecolotree ${ }^{\mathbb{R}}$, Inc., the project industry partner in October 2001. The visit included a tour of ET vegetative cover and reactive barrier sites that have been installed in the area as well as project-related discussions. Topics discussed with Ecolotree ${ }^{\circledR}$ researchers during the visit included:

- The use of Hydrus-2D modeling software as a data organization, manipulation, and presentation tool.

- The results of a head-to-head comparison of an ET vegetative cap installed by Ecolotree ${ }^{\circledR}$ as part of the EPA ACAP study in Albany, Georgia. The study shows that virtually no percolation (i.e., leaching) is occurring from the cell with the ECap ${ }^{\mathrm{TM}}$. This is of importance because the environment at Albany, Georgia, is similar to that at SRS, and the results achieved at Albany could be expected to also occur at SRS.

- The types and species of plants that could be used as part of a vegetative cover at SRS.

- Whether or not radionuclides might be taken up in the vegetation and what the disposition of this material within the plant structure might be. The type of information may influence the contingency plan being drawn up for the potential future removal of this type of cover.

Dr. Louis Licht, Ecolotree ${ }^{\circledR}$ President, visited the EERC during November 2001. He toured the facilities, presented information about ET covers and Ecolotree ${ }^{\circledR}$ history at an informal gathering of EERC researchers and discussed the project plans with project personnel.

Melanie Jensen attended both conferences and presented a poster at the midyear review entitled "EM Technical Assistance Through a NETL-EERC Partnership," coauthored with Tina Behr-Andres, Erin O'Leary, and Thea Reilkoff. A two-page summary paper of the same title was also prepared for the program reviewers in attendance at the conference. The poster discussed all of the projects that are currently a part of the ETA cooperative agreement while highlighting the vegetative cover project.

The technical presentations of ET vegetative covers at both conferences indicated that the approach that is being taken on this project is on target with other vegetative cover research performed at various sites around the complex.

Multiple attempts have been made to enter into meaningful dialogue with personnel at SRS about the design of an ET vegetative cover for placement at a LLW repository there. For many 
reasons, including the uncertainty posed by the Environmental Management (EM) top-to-bottom review and subsequent administrative transition plans, it has not been possible to discuss project direction for this task with them.

To advance this project, various EM personnel will be contacted as the search for an appropriate site continues. Alternatives to SRS are being considered, including performing the cover design for another EM site (such as one in Ohio) or possibly at Chem-Nuclear's Barnwell, South Carolina, LLW disposal facility.

\section{References}

1. Serrato, M. Long-Term Capping Strategy and Technical Program. Presented at Waste Management '02, Tucson, AZ, Feb 2002; Session 58, Paper 1.

2. NatureServe Explorer: An On-Line Encyclopedia of Life [Web application]. 2001. Version 1.6. Arlington, VA, USA: NatureServe. http://www.natureserve.org/explorer.

\section{TASK 4 - SYSTEMS ENGINEERING}

There were three major activities in the Systems Engineering task during this 6-month time period: assisting the Deactivation and Decommissioning Focus Area (DDFA) in the annual technical response to site needs; developing a Web version of D\&D Information System (DDIS); and creating a beta version of a complexwide information system for technology assistance, called the EM Technology Assistance System (EMTAS).

\section{Technical Response to Site Needs}

In preparation for the annual DDFA technical response to site needs, the DDIS was updated with new technologies. These technologies were gleaned from the Technology Management System (TMS), the industry review report created by the EERC last spring, and from various vendor exhibitions. Each technology was assigned properties, which are used to automatically map technologies to needs. DDIS now contains over 500 technologies which may provide a solution or partial solution to a D\&D problem.

Many of the sites held needs workshops in October and November. These workshops are used to bring together site end users, site technology coordinating group members, and focus area members to review existing needs and develop new needs. The EERC attended the Richland needs workshop. After the workshops were completed, the appropriate revisions and additions of needs from each site were input into DDIS. We also assisted DDFA by preparing the technical needs response for the Richland and Albuquerque site needs. A meeting was held at the National Energy Technology Laboratory (NETL) in late January to review all of the responses. DDFA team members input their technical responses into DDIS. The EERC then exported the data as a batch upload into the IPABS. 


\section{Web Version of DDIS}

Because of the successful implementation of the information system for the Focus Area, DDIS was made available to the general public through the World Wide Web in January 2002 (www1.undeerc.org/ddis). This new Web-based system offers many opportunities to site end users, project managers, technology developers, and vendors that have not been available in the past, such as the following.

\section{Site End Users}

- Finding technologies that may solve a particular problem. The need may be already in the database or can be defined using the hierarchical search feature.

- Examining the disposition of needs across the complex that are similar to a specific site problem.

- Reviewing the projects that are in place to address a specific need.

- Reviewing the status and priority of the needs at a specific site and across the complex.

\section{Technology Vendors/Developers}

- Finding descriptive and contact information on needs that matches the capabilities of the vendor's technology.

- Discovering areas where technology development is needed by finding needs which have limited or no potential solution.

- Submitting the technology for review and possible inclusion in the database.

\section{Complexwide Technology Assistance - EMTAS}

DDIS was presented at several conferences such as Spectrum and Waste Management. In addition, the EERC participated as the D\&D representative in the Office of Science \& Technology (OST) Information Systems Working Group. Through discussions with site technology end users, focus area representatives, and vendors, it became clear that there was a need for a system such as DDIS to be expanded to include all of the focus areas. It was also apparent that there were many issues regarding data entry and maintenance in IPABS, focus area information systems, and sitemaintained information systems. In December 2001, the EERC met with staff from the Office of Technology Applications (EM-54) and EM Office of Management and Information (EM-7) to discuss methods of integrating an expanded DDIS across the complex and with existing OST information management systems, such as IPABS. We received the recommendation and approval from EM-54 to proceed with the development of this system within the EERC-NETL Cooperative Agreement.

The planned activity was to create the EMTAS as the successor to DDIS, expanding on the idea of the single source needs-technology system by including all site needs (no longer limited to 
D\&D) and a broader inventory of core and alternative technologies with the potential to address the needs. EMTAS would provide the same benefits to site end users, project managers, technology developers, and vendors as DDIS, with the addition of providing:

- Real-time data entry of site problems and technical solutions, using a systems engineering approach designed to facilitate matching of problems to potential solutions.

- Fast and flexible communication between sites, headquarters, technology vendors, and the research community.

- Capability to be easily adapted to programmatic or site-requested changes.

- Capability for integration with IPABS and site-maintained systems.

The EERC met with representatives from the Nuclear Materials Focus Area, the transuranic (TRU) and Mixed Waste Focus Area, and representatives from INEEL and the Albuquerque Operations Office in January 2002 to present and discuss the future applicability of EMTAS. A beta version of EMTAS is available at www1.undeerc.org/emtas. 